\title{
Sector performance under inflationary conditions
}

\author{
A. Archer \\ University of Stellenbosch Business School
}

The effects of inflation are substantial, widespread and differential. The author investigated the effect of inflation on the published income of 19 industrial sectors of the Johan. nesburg Stock Exchange. The various adjustments for the effects of inflation recommended by Guideline 4.003 of the S A Institute of Chartered Accountants were made to the publish. ed income of individual companies and accumulated to gain a perspective of sector performance. Possible reasons for the exceptionally large adjustments in a few sectors are discus. sed. Measures which could be introduced by companies to counter the effects of inflation are explained.

S. Afr. J. Bus. Mgmt. 1981, 12: 5-8

Die gevolge van inflasie is aansienlik, verspreid en differensieel van aard. Die skrywer het die effek van inflasie op die gepubliseerde inkomste van die 19 nywerheidsektore van die Johannesburgse Effektebeurs ondersoek. Die verskillende regstellings of aanpassings vir die effek van inflasie, soos aanbeveel deur Riglyn 4.003 van die S A Instituut van Geoktrooieerde Rekenmeesters, is aan die gepubliseerde inkomste van individuele maatskappye gemaak en geakkumuleer om 'n perspektief oor sektorprestasie te verkry. Moontlike redes vir buitengewoon hoë regstellings in 'n paar sektore word bespreek. Maatreêls wat deur maatskappye getref kan word om die effek van inflasie teen te werk, word bespreek.

S.-Afr. Tydskr. Bedryfsl. 1981, 12: 5-8
Since 1974, when the annual inflation rate (as measured by changes in the consumer price index) reached doubledigit figures, the attention of management has been more sharply focussed on the effects of rising price levels. As pointed out by Chambers ${ }^{1, p .6}$, the real effects of price variations and of inflation are substantial, widespread and differential. Businessmen and other interested parties should be informed of their magnitude. If the traditional business accounting process confuses the results of trading with the effects of inflation, there is no way of knowing what is happening to any firm or to any industry. Decisions which flow from misreported or miscalculated results cannot therefore be well founded.

If historical published figures are not in some way or other adjusted for the effects of inflation they are, under conditions of a steep rise in the price level, virtually meaningless.

Mason, as quoted by Gynther ${ }^{2, p .14}$ summarized the problem rather well. He maintained that, without adjustment of figures for the effects of inflation, the income statement suffers from price level changes by the lack of comparability of the accounting figures, from the failure of depreciation and similar costs to reflect the current price level and therefore to be comparable with the current revenue figures and from the resulting diminished significance of the reported net income. The balance sheet also suffers from lack of comparability of the various items. Cash and receivables and the unpaid liabilities are expressed in current monetary units, but the stocks and especially plant and equipment are collections of non-comparable items since they are almost always a hodge-podge of various past-period monetary units representing different amounts of purchasing power. The purchasing power gains and losses on the net monetary position are undisclosed. Shareholders and other investors are not provided with information which enables them to interpret the operating results and to judge the relative effect of price-level changes on a particular enterprise.

In publishing the Guideline No 4.003 on the Disclosure of effects of changing prices on financial results, in August 1978, the National Council of Chartered Accounts (SA) (now called the SA Institute of Chartered Accountants) paved the way for more meaningful financial results to be published. 


\section{Scope and method of the research}

In order to make the adjustments to the published income of companies, according to the recommendations of Guideline 4.003 , a computer model was developed. The three basic adjustments required are: for stocks, additional depreciation and for the way in which a firm is financed. The model was designed so that it could cater for a wide variety of inputs e.g. different ways of classifying assets and liabilities and different inflation rates for stocks and depreciable assets per company per year.

The published results of 256 listed industrial companies for the period 1970 to 1979 were evaluated before and after the required adjustments were made. In addition, questionnaires were sent out to these companies to obtain additional information. In total 168 companies or $65,6 \%$ returned usable questionnaires. ${ }^{3}$

A number of assumptions had to be made of which the more important ones are:

- All investments, including loan levies, were classified as non-monetary assets. The effect of this classification is to increase the gearing ratio, leading to 'better' adjusted income figures being produced.

- The average age of depreciable fixed assets was estimated to be:

Accumulated depreciation divided by depreciation in Income statement.

An overriding limit of 5 years was imposed, the effect of which again is to produce 'better' adjusted results in the case of most companies.

- Changes in the prices of fixed assets were assumed to be equal to changes in the consumer price index.

- A variety of inflation rates for stocks were used for individual companies in the various sectors. These inflation rates had to be estimated based on information obtained through the questionnaires and interviews with company of ficials.

- Fixed assets were not revalued, again having the effect of producing 'better' adjusted results.

The individual results of companies were accumulated on a per year per sector basis. The classification of companies in the 19 sectors was done as per the classification of the Johannesburg Stock Exchange.

\section{The research findings}

Linear trends over time in historical income after taxation per sector were determined after the average income of all the companies in a sector was calculated and indexed with 1975 income equal to 100 . It was established that all the sectors managed to increase historical income after taxation significantly at the $5 \%$ level during the period 1970 to 1979.

In the case of historical dividend covers nine sectors increased historical covers significantly at the $5 \%$ level whilst 13 did so at the $10 \%$ level. Six sectors kept historical dividend covers virtually stable during 1970 to 1979. They are Building $\&$ Construction; Electronics, Electrical \& Battery; Motors; Steel \& Allied; Stores and Sugar. This is surprising since one would expect historical dividend covers to increase under continued inflationary conditions in order to conserve cash. Furthermore, an investigation into the historical dividend covers of these sectors in 1970 reveals that they were not exceptionally high compared to other sectors in that year.

If the linear trends in adjusted (i.e. for the effects of inflation) income after taxation are investigated it appears that out of the 19 sectors 16 increased adjusted income significantly at the $10 \%$ level, whereas the Motor sector had a significant negative trend. The Printing \& Publishing and Clothing, Footwear, Textiles sectors managed to keep their adjusted incomes relatively stable. One can conclude, therefore, that, with the exception of the three sectors mentioned, the others all succeeded in increasing income after taxation after the effects of inflation had been accounted for.

A study of adjusted dividend covers reveals another side of the picture. Only one sector, viz. Transportation, succeeded in increasing adjusted dividend cover significantly $(5 \%$ level) during the period. Ten sectors had stable trends whereas eight sectors actually decreased adjusted dividend covers significantly at the $10 \%$ level. They are Building \& Construction; Clothing, Footwear, Textiles; Furniture \& Household Goods; Electronics, Electrical \& Battery; Motor; Printing \& Publishing; Stores and Sugar. The danger of an adjusted dividend cover below one is therefore real should this trend continue.

\section{Analysis of the various adjustments}

It would be of interest to study the various adjustments to historical income after taxation on a per sector basis to try and establish the reasons for abnormally high or low adjustments. Only the 1979 results will be analysed of which a summary appears in Table 1.

From the table it can be seen that the sectors with an adjustment greater than $50 \%$ in historical income after taxation are Clothing, Footwear, Textiles $(58,3 \%)$; Furniture \& Household Goods $(63,4 \%)$; Electronics, Electrical \& Battery $(50,3 \%)$; Motor $(\mathbf{7 3 , 5 \% )}$ and Stores $(54,8 \%)$.

The reasons for the relatively large adjustments in the total income of the above-mentioned sectors are as follows.

\section{Clothing, Footwear, Textiles}

The biggest single adjustment is for stocks because of the relatively large stockholding, i.e. $31,7 \%$ of assets (see Table 2). Secondly, the total loss on the gearing adjustment, i.e. 11,9\% (see Table 1) is higher than the gain, i.e. $10,9 \%$ (see Table 1). Clearly, companies in this sector must investigate the possibilities of changing to the LIFO method of stock valuation and try to change their working capital cycle to increase short-term gearing. If that is not feasible, an examination of the business and financial risks could lead to more long-term outside funds being brought into the capital structure. At the end of 1979 the $7,3 \%$ (see Table 2) of total liabilities in the form of longterm loans was amongst the lowest in all sectors.

\section{Furniture \& Household goods}

As in the case of the Clothing sector, the stock adjustment is rather high, i.e. $\mathbf{2 6 , 2 \%}$. But, the single most important adjustment in this case is the loss on the holding of monetary assets, i.e. $\mathbf{3 0 , 4 \%}$. The reason is to be found in the substantial investment in Debtors, i.e. $68,5 \%$ (see 
Table 1 Adjustments to historical income on a per sector basis for 1979*

\begin{tabular}{|c|c|c|c|c|c|c|c|c|c|c|c|c|c|c|c|c|c|c|c|}
\hline & 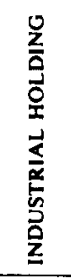 & 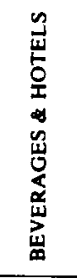 & 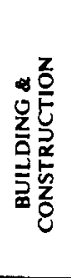 & 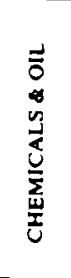 & 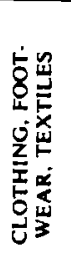 & ఫి & $\frac{0}{\underline{z}}$ & 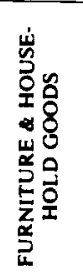 & $\begin{array}{l}\frac{0}{2} \\
\frac{z}{\underline{u}} \\
\underline{w} \\
\frac{z}{0} \\
\frac{z}{w}\end{array}$ & 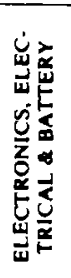 & $\begin{array}{l}\frac{0}{0} \\
\frac{0}{2} \\
\frac{0}{2}\end{array}$ & 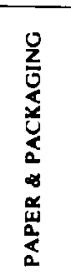 & 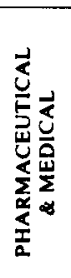 & 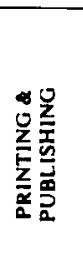 & 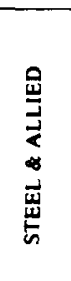 & 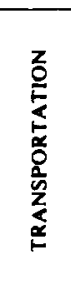 & 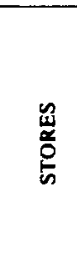 & 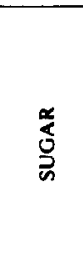 & 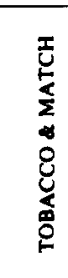 \\
\hline Historical income after taxation & 100,0 & 100,0 & 100.0 & 100,0 & 100,0 & 100,0 & 100,0 & 100,0 & 100,0 & 100,0 & 100,0 & 100,0 & 100,0 & 100.0 & 100,0 & 100,0 & 100,0 & 100,0 & 100,0 \\
\hline \multicolumn{20}{|l|}{ Adjustments: } \\
\hline Stock: LIFO"* & & & 0,8 & 6,9 & 9,8 & & & 0,3 & 7,9 & 8.5 & & 8,6 & & & 2.6 & & 1,1 & 1.5 & \\
\hline Stock: Other & $(36,0)$ & $(26,1)$ & $(24,1)$ & $(17,7)$ & $(34,2)$ & $(38,1)$ & $(7,8)$ & $(26,2)$ & $(33,9)$ & $(25,8)$ & $(73,3)$ & $(18,0)$ & $(42,1)$ & $(23,4)$ & $(16,7)$ & $(0,7)$ & $(70,6)$ & $(15,8)$ & $(43,1)$ \\
\hline Additional depreciation & $(22,7)$ & $(14,6)$ & $(32,7)$ & $(32,3)$ & $(23,1)$ & $(36,5)$ & $(13,9)$ & $(9,4)$ & $(24,8)$ & (23.5) & $(33,6)$ & $(28.7)$ & $(9,0)$ & $(30,9)$ & $(38,6)$ & $(31,2)$ & $(16,1)$ & $(19,8)$ & (13,8) \\
\hline Gain: Net Monetary Liabilities & 16.3 & 13,0 & 17,1 & 22,6 & 10.9 & 25.2 & 0,7 & 2.6 & 12,7 & 8.5 & 34,9 & 12,7 & 16.5 & 7,7 & 18,4 & 30.7 & 32.9 & 10.7 & 11,0 \\
\hline Loss: Net Monetary Assets & $(0,3)$ & & $(0,4)$ & & $(11,9)$ & $(0.2)$ & $(18,7)$ & $(30,4)$ & $(3,1)$ & $(8,9)$ & $(1,5)$ & $(0,2)$ & $(2,7)$ & (3.2) & & & $(0.6)$ & $(0.1)$ & \\
\hline Total adjustments & $(42,7)$ & $(27,7)$ & $(40.1)$ & $(27,4)$ & $(58,3)$ & $(49,6)$ & $(39,7)$ & $(63,4)$ & $(49,1)$ & $(49,7)$ & $(73,5)$ & $(34,2)$ & $(37,3)$ & $(49,8)$ & $(36,9)$ & $(8,2)$ & $(54,8)$ & $(25.0)$ & $(45,9)$ \\
\hline Adjusted income & 57,3 & 72,3 & 99,9 & 72,6 & 41,7 & 50.4 & 60,3 & 36.6 & 50,9 & 50.3 & 26,9 & 69,8 & 62.7 & 50,2 & 63.1 & 91,8 & 45,2 & 75,0 & 54,1 \\
\hline Historical dividend cover & 2.69 & 2,16 & 2,20 & 1.97 & 3,39 & 2,84 & 2,13 & 3,17 & 2.18 & 1,62 & 2.51 & 2.29 & 2,38 & 3.38 & 2.54 & 3.71 & 2,14 & 1.53 & 3.88 \\
\hline Adjusted dividend cover & 1,58 & 1,52 & 1,32 & 1,40 & 1,37 & 1,36 & 1,25 & 1.13 & 1.10 & 0.80 & 0.63 & 1,51 & 1,48 & 1.68 & 1.59 & 3,42 & 0.93 & 1.15 & 2.09 \\
\hline
\end{tabular}

Table 2). The situation for the retailers in this sector is rather difficult because of the large percentage of goods sold on hire-purchase or other terms. The LIFO system is also perhaps not suitable due to regular changes in models. The only solution could be higher gross margins or higher historical dividend covers if the danger of an adjusted cover below one is real.

\section{Electronics, Electrical \& Battery}

A combination of stock adjustments and additional depreciation is responsible for an adjustment of over $50 \%$. The loss on the holding of monetary assets, i.e. $8,9 \%$, is higher than the gain on monetary liabilities, i.e. $8,5 \%$ (see Table 1). A few companies in this sector are already using the LIFO method of stock valuation and it seems as if more could investigate switching.

\section{Motor}

The Motor sector has the second largest percentage stockholding of all the sectors, i.e. $37,0 \%$ of total assets in 1979 (see Table 2). This is responsible for a stock adjustment of 73,3\% of historical income (see Table 1) which is the highest of all the sectors. The adjustment for additional depreciation is the third highest of all the sectors, i.e. $33,6 \%$. These substantial adjustments are to an extent offset by a $34,9 \%$ adjustment which is the gain for holding net monetary liabilities. It could be feasible for some of the companies in this sector to investigate changing to the LIFO method of stock valuation.

\section{Stores}

The Stores sector, with the largest stockholding of all sectors $(44,1 \%$ of total assets, see Table 2$)$, has the second

Table 2 Balance sheet per sector for 1979 (in percentages)

\begin{tabular}{|c|c|c|c|c|c|c|c|c|c|c|c|c|c|c|c|c|c|c|c|}
\hline ASSETS & 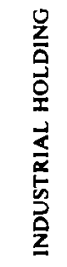 & 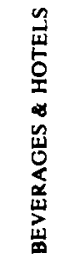 & 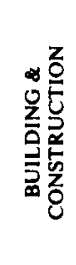 & 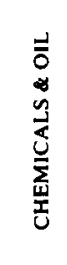 & 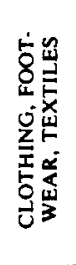 & ठి & $\frac{\text { U }}{\frac{1}{I}}$ & 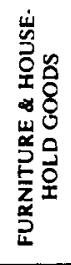 & 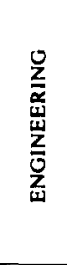 & 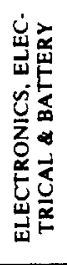 & $\begin{array}{l}\frac{N}{0} \\
\frac{0}{2} \\
\frac{0}{\Sigma}\end{array}$ & 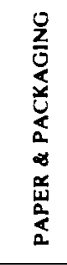 & 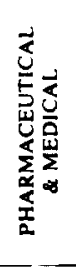 & 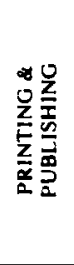 & 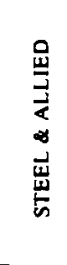 & 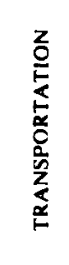 & $\begin{array}{l}\stackrel{a}{u} \\
\frac{a}{0} \\
\stackrel{5}{n}\end{array}$ & 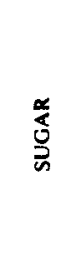 & 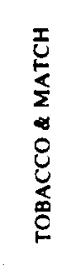 \\
\hline Land and buildings & 14,5 & 22,9 & 14,5 & 9,2 & 13,7 & 22.3 & 10,7 & 3.9 & 13,0 & 15.6 & 18,8 & 15,5 & 14,8 & 27,1 & 12,7 & 2,9 & 15,0 & 27,2 & 6,7 \\
\hline Other Fixed assets & 20,0 & 21,8 & 34.6 & 34,0 & 8.4 & 16.7 & 5.2 & 4.5 & 18,6 & 21.1 & 9,9 & 31,2 & 9,3 & 20,0 & 44,1 & 79.4 & 10,4 & 36.8 & 6,0 \\
\hline Goodwill & 0,9 & 1,2 & 0.2 & 1,3 & 0.3 & 0,4 & 3.6 & 0,6 & 0,1 & 0,0 & 0,1 & 1,1 & 2.0 & 0,4 & 0,0 & 0,2 & 0,8 & 0,0 & 1,2 \\
\hline Investments & 8,5 & 5,0 & 5,1 & 7,2 & 6.2 & 6,9 & 29,3 & 3,1 & 9,9 & 1,7 & 7,2 & 1,4 & 7,4 & 3.7 & 1,6 & 3,7 & 2,2 & 7,5 & 35.2 \\
\hline Loan levies & 1.3 & 1.7 & 1,2 & 0.5 & 1,5 & 1,6 & 2,8 & 1,3 & 1,3 & 3.0 & 1,1 & 2.3 & 2,5 & 1,0 & 0,7 & 0,4 & 2,3 & 1.0 & 1,0 \\
\hline Stocks & 26,0 & 24,3 & 15.2 & 20,8 & 31,7 & 24,1 & 6,2 & 16.7 & 24,8 & 26,5 & 37,0 & 24.9 & 31,1 & 17.7 & 19,9 & 2.3 & 44.1 & 11.5 & 26.8 \\
\hline Debtors & 25,0 & 22,3 & 23,3 & 20,9 & 36,6 & 25,3 & 14,6 & 68,5 & 27,3 & 19,6 & 24.2 & 19.6 & 28,1 & 22.4 & 18,2 & 6.5 & 21.1 & 13,6 & 10,8 \\
\hline \multirow[t]{2}{*}{ Other Current assets } & 3,8 & 0.8 & 5,9 & 6,1 & 1,6 & 2.7 & 27,6 & 1,4 & 5.0 & 12.5 & 1,7 & 4,0 & 4,8 & 5,7 & 2,8 & 4,6 & 4,1 & 2,4 & 12,3 \\
\hline & 100,0 & 100,0 & 100,0 & 100.0 & 100,0 & 100,0 & 100,0 & 100,0 & 100,0 & 100,0 & 100,0 & 100,0 & 100.0 & 100,0 & 100,0 & 100,0 & 100,0 & 100,0 & 100,0 \\
\hline \multicolumn{20}{|l|}{ LIABILITIES } \\
\hline Shareholders' interest & 36,4 & 38,1 & 45,7 & 42,2 & 53,9 & 38,2 & 55.1 & 35.7 & 51,3 & 61.2 & 46,3 & 50,6 & 45,5 & 53,0 & 42,7 & 19,4 & 42,6 & 57.7 & 70.4 \\
\hline Outside interest & 11,3 & 9,0 & 2,2 & 1,2 & 1,9 & 4,2 & 11.5 & 2.7 & 1.3 & 0,3 & 3,8 & 4,5 & 1.7 & 9,8 & 1,8 & 0,4 & 0,4 & 7,2 & 0,3 \\
\hline Preference shares & 0,6 & 4,9 & 1,2 & 1,6 & 1,8 & 2.5 & 4,9 & 0.5 & 0,9 & 1,3 & 1,1 & 1.0 & 1.6 & 0,2 & 0,6 & 0,0 & 1,5 & 2,3 & 0,2 \\
\hline Long-term loans & 12,0 & 17,5 & 12,7 & 19,8 & 7.3 & 12,2 & 6,2 & 10.0 & 13,3 & 6,5 & 9,3 & 13.1 & 11,6 & 5.7 & 10,4 & 60,1 & 10,9 & 12,3 & 8,2 \\
\hline Deferred taxation & 2,8 & 2.4 & 5,7 & 4,9 & 1.0 & 2,0 & 0.8 & 9,0 & 1,5 & 1,2 & 1,8 & 1.8 & 0.9 & 1,1 & 10,8 & 8,1 & 0.6 & 2.9 & 0.4 \\
\hline Creditors & 20,9 & 15,6 & 20,0 & 14,7 & 21,2 & 19,2 & 9.5 & 27,1 & 22,2 & 17,5 & 27,7 & 16.2 & 22,3 & 19.5 & 14,5 & 10.2 & 30,4 & 10,9 & 13.0 \\
\hline \multirow[t]{2}{*}{ Other Current liabilities } & 16,0 & 12,5 & 12,3 & 15,6 & 12,9 & 21,7 & 12,0 & 19,0 & 9,5 & 12,0 & 10,0 & 12,8 & 16,4 & 10.7 & 19,2 & 1.8 & 13.6 & 6.7 & 7.5 \\
\hline & 100,0 & 100,0 & 100,0 & 100,0 & 100.0 & 100,0 & 100,0 & 100,0 & 100,0 & 100,0 & 100,0 & 100,0 & 100,0 & 100,0 & 100,0 & 100,0 & 100,0 & 100,0 & 100.0 \\
\hline
\end{tabular}


largest stock adjustment. i.e. $70,6 \%$ of historical icome. Again, as in the case of the Motor sector, the adjustment is offset by a substantial gain resulting from the holding of net monetary liabilities. One could reasonably expect to see more companies in future changing to the LIFO method of stock valuation which will reduce the substantial stock adjustment and increase cash flow.

\section{Measures to counter the effects of inflation}

Three sectors had an adjusted or real dividend cover less than one in 1979. Obviously this does not imply that all the companies in these sectors had real dividend covers less than one. In total, over $31 \%$ of the 256 companies in the survey had adjusted dividend covers less than one in 1979. Measures which could be introduced to rectify the situation are discussed below:

- companies could introduce an internal system of inflation accounting

- companies could start with the introduction of a policy of revalueing fixed assets at regular time intervals and/or writing off of additional depreciation

- the LIFO method of stock valuation could probably be used by many more companies
- the more effective use of gearing for those companies which have low historical return ratios could be investigated. Companies with relatively high historical return ratios do not need the effect of gearing to the same extent as those with low return ratios

- a substantial number of companies could increase their dividend covers, in order to retain more cash in the business and avoid the danger of a real cover below one

- the overall improvement of efficiency can play an important role. In this regard it has to be noted that no system of inflation accounting can be a remedy for bad management.

\section{References}

1 CHAMBERS, R.J. Accounting for Inflation, The University of Sydney, Sydney, 1975.

2 GYNTHER, R.S. Accounting for Price-level changes - Theory and Procedures, Pergamon Press, Oxford, 1966.

3 ARCHER, A. The Relevance of Guideline 4.003 (of the S A Institute of Chartered Accountants) for Financing and Dividend Policy Decisions, Unpublished doctoral dissertation, University of Stellenbosch, 1980. 